Theological Research • volume 7 (2019) • P. 53-67 doi: http://dx.doi.org/Io.15633/thr.3951

Marcin Suskiewicz

HTTPS://ORCID.ORG/OOOO-0002-3279-657I

University of Oxford

\title{
Messianism and Modernity. Commentary to the Liturgy of History
}

\section{Abstract}

In his recent book Liturgia dziejów [Liturgy of History], Paweł Rojek argues that Karol Wojtyła was to a large extent influenced by Polish Messianism. Although Rojek's argument centres around this rather historical thesis, his book is essential reading not only for students of John Paul II's legacy but anyone interested in the relationship between Christianity and modernity. It is so, because Polish Messianism, according to Rojek, was an early project of Christian modernity. By taking inspiration from the Messianists, Wojtyła was able to combine religious perspective with modern anthropocentrism.

Keywords

John Paul II, Messianism, Romanticism, modernity, millenarism, Paweł Rojek

I An earlier version of this paper has been published in Polish as M. Suskiewicz, Inna nowoczesnośc jest możliwa, "Suma" 6 (2017-2018), http://pismosuma.pl/inna-nowoczesnosc/ (22.04.2021). 
"For hundreds of young men [at nineteenth-century Oxford]," famously wrote James Froude (one of those young men and later a Victorian man of letters), "Credo in Nerwmanum was the genuine symbol of faith." The Christianity in which the then students of Oxford believed had a particular face, that of the theologian John Henry Newman. Were it not for its clumsy Latin, the phrase Credo in Wojtylanum (or would it be Wojtylum?) could be used, by analogy, to describe the faith of millions in Poland from 1978 to early 2005. It was from Karol Wojtyła, better known as the Pope John Paul II, that we wanted to learn how to understand our Catholic faith and how to put it to life. In his recent book Liturgia dziejów [Liturgy of History], the Krakow philosopher Paweł Rojek argues that Wojtyła, in turn, learnt from Polish romantic thinkers of the so-called messianic vein. ${ }^{3}$ Although Rojek's argument centres around this one thesis, it should not be dismissed as a mere exercise in what in Polish humanities has been mocked as "influencology" ("wplywologia"), the often-futile study of artistic and intellectual influences for its own sake. What is really at stake here is placing Wojtyła in a particular tradition; having achieved that (to this reviewer at least, satisfactorily), Rojek goes on to provide a reading of Wojtyła's teaching and the Christian message itself that amounts to a bold and timely political manifesto. All this makes Rojek's book an essential reading not only for students of John Paul II's legacy but anyone interested in the relationship between Christianity and modernity.

\section{Sources of Messianism}

Rojek's insistence on "Messianism" instead of a more neutral "Polish Romanticism" is deliberate but is bound to raise eyebrows, especially among readers familiar with a pejorative connotation of this term in Polish humanities. After all, is not Messianism typically associated with the controversial religious leader of Polish émigrés in France, Andrzej Towiański (I799-I878), and his outlandish, heterodox mysticism? Although Towiański still inspires awe for having succeeded in attracting

2 J. A. Froude, Short Studies on Great Subjects, London I907, p. 246.

3 P. Rojek, Liturgia dziejów. Jan Pawet II i polski mesjanizm, Kraków 20I6; see P. Rojek, John Paul II and the Polish Messianism. Introduction to the Liturgy of History, transl. by K. Popowicz, "Theological Research" 7 (2019), p. 9-27. 
to his cause some of the greatest Polish romantics, few contemporary thinkers have tried to revive him, and Rojek, for all his daring, is not interested in doing that either. On the contrary, he goes to a considerable length to dissociate Messianism from its dominant connotations and indeed from any single mystic, poet, or philosopher. It is necessary, says Rojek, to break through the spectacular but accidental and focus on the essential. Seen through this logic, Messianism is associated with individual historical figures like Mickiewicz (and not primarily with Towiański) only in so far as they were particularly persuasive in giving voice to a certain message; and collectively with the messianic movement only in so far as it provided an environment in which such an articulation could be developed in an on-going conversation. What really matters, however, is the message itself, even if learning more about the romantics and their vocabulary might be necessary to crack it. In fact, Rojek will argue, sometimes it is best to look at the final, most mature form of Messianism - epitomised by the papal teaching of John Paul II - to figure out what was the real lifeblood of this movement from the beginning. In this sense, not only romantics tell us something about Wojtyła, but also Wojtyła feeds back on romantics.

The romantics here include the likes of Józef Hoene-Wroński ( $1776-$ I853), Adam Mickiewicz (I798-I855), Juliusz Słowacki (I809-I849), Zygmunt Krasiński (I8I2-I859), Cyprian Kamil Norwid (I82I-I883), and August Cieszkowski (1814-I894), to name just the main few. Importantly, all of them lived and wrote during the time of the so-called partitions of Poland, when their homeland did not exist as a sovereign state. Some of them were part of the so-called Great Emigration, a diaspora of Polish political and cultural elite in France that formed after the failed November Uprising of 1831. Also of note, they generally came after the archetypic European romantics such as Novalis, Lord Byron, or Schiller, further into the long nineteenth century and the societal and technological changes which it brought - and yet they seem to have been more genuinely religious. Finally, four of Rojek's protagonists - Mickewicz, Słowacki, Krasiński, and Norwid - take central stage in most accounts of the history of Polish literature, with the first three being known as "Three Bards" or "Three Prophets." Although not well-known outside Poland, these names are crucial for Polish self-identity. It is therefore only fitting that they should be linked to the figure that arguably looms largest in the recent Polish history, namely Karol Wojtyła or John Paul II. 
Some elements of this account have been known. This all-too-familiar story goes something like this: Wojtyła was clearly influenced by romantics in the poetic and theatrical projects undertaken in his student days, and later, as a pope, often cited Norwid, who might have inspired him to defend the human dimension of work. So, the story implies, the romantic influence is there, but is secondary to more important influences such as the phenomenology, the Second Vatican Council, or even Carmelite spirituality. Rojek claims, however, that the familiar story is not only incomplete, but actually needs a radical retelling. According to him, what Wojtyła took from Messianism are not negligible ornaments, but the very strategy for being religious in the modern age. In this way, he remained a "Messianist" as a priest, a bishop, and one of the fathers at the Second Vatican Council, and the pope.

To prove the link between Messianism and Wojtyła, Rojek provides us first with his messianic pedigree, a chain of names linking the romantics to the future pope. ${ }^{4}$ In the last stage, three names are key, in addition, naturally, to Wojtyła's reading list, heavy with romantic literature. The first and foremost is the forgotten Polish philosopher and Catholic activist Jerzy Braun (I90I-1975). A keen reader of the romantics and himself an avowed Messianist, Braun was, among his other initiatives, a leader of the secret organisation Unia, to which young Wojtyła belonged from 1940 to his entrance into a seminary in 1942. In the dark days of Nazi occupation, Unia tried to educate its members morally and intellectually in what looks very much like a messianistic curriculum, and, additionally, to draft a programme for the future independent Poland, again in line with the ideas of the Polish romantics. The connection between Wojtyła and Braun survived far beyond 1942 until the latter's death in 1975 . The second important channel of messianistic legacy was Mieczysław Kotlarczyk (1908-1978), Wojtyła's mentor in the romantically-inspired underground Rhapsodic Theatre (formally a branch of Unia), his penfriend, and also flatmate for some time. Their correspondence, as Rojek shows, abounds in messianistic themes. And the third influence is Stanisław Pigon, a literary historian at the Jagiellonian University in Krakow, where Wojtyła studied Polish literature before entering a seminary. Pigoń was once a member of Eleusis, a somewhat bizarre society inspired by Messianism (and specifically Towiański). Later, along other former

P. Rojek, Liturgia dziejów, op. cit., p. 99-I39. 
members of this movement, he pioneered first scouting groups in Poland, where he would prescribe reading Mickiewicz's The Books of the Polish People and of the Polish Pilgrimage for one hour per week. By the way, Braun was also a devoted scout, and Rojek - himself a former scout - makes a convincing claim for Polish scouting being originally steeped in Messianism.

It is not difficult to demonstrate romantic influences in Wojtyła's early literary output. But what Rojek really manages to bring home is that these influences were primarily on the level of ideas, and not only stylistic. And even more importantly, as I have already mentioned, Rojek claims that Messianism stayed with Wojtyła throughout his life. This isn't obvious, because generally messianistic references were rarer the older Wojtyła grew, giving way to references to the documents of the Second Vatican Council. However, Rojek has a solution to this conundrum. Messianistic ideas in many respects anticipated those expressed at the Council and therefore Wojtyła could stay faithful to his messianistic programme without openly referring to it. A bold claim, to be sure, but Rojek manages to make it credible.

The main message of Messianism turns out to be relatively simple. Rojek argues that the verbose and often obscure texts of Polish romantics can be pared down to three components, which he labels with oneword titles. The first one is millenarism, that is to say a call to transform the temporal order through human effort. The second one is missionism, or a belief in nations and peoples having their special God-given tasks to fulfil. And the third and final one is passionism, that is an understanding of collective suffering as redemptive or at least, more broadly, meaningful. Millenarism, missionism, passionism, these three; but the greatest of these is millenarism.

While the choice of the esoteric "isms" (two of them of the author's own coinage and none of them used by the romantics or Wojtyła themselves) might deter some readers, generally speaking Rojek's reduction of Messianism to three simple tenets is persuasive and does introduce some clarity into cloudy waters of messianistic literary legacy. Perhaps the only objection could be that generally Rojek bases his analysis on short sentences and paragraphs from the romantics, and, additionally, not necessarily from their major works. This, I think, makes it difficult to judge how central the messianistic ideas really were to their overall oeuvre. But that they do exist, hidden between the romantic lines, seems fairly settled. 
Trained in the analytic philosophical tradition, Rojek has a gift for making complex stories simple and logical. His lucid, Anglosaxon tone comes complete with an occasional witticism and simple tables. Sometimes the contrast between arcane ideas and a simple tabular format creates a comical effect. In one such table, for example, various thinkers are analysed with respect to the three identified elements of Messianism (millenarism, missionism, and passionism); reassuringly, Mickiewicz, Krasiński, and Wojtyła all get three pluses; other analysed thinkers generally do not. ${ }^{5}$

Uniquely - but perhaps fittingly for an intellectual from a country stranded between the East and the West - Rojek combines his analytic leanings with a theological sensitivity of a somewhat Eastern Orthodox tone that brings to mind Vladimir Solovyov or Pavel Florensky, both of whom have been, in fact, important influences. Thus, for example, Rojek neatly relates the three elements that he detected to the patristic (but actually also Protestant) doctrine of the threefold office of Christ as a king, a prophet, and a priest. Indeed, one way of summarising Rojek's take on Messianism is to say that for him the so-called messianic hope consists in our readiness to take on these three offices of Christ, not just in waiting for Christ to fulfil them for us.

Since the linchpin of Messianism is millenarism, it is to the latter that Liturgia dziejow is really dedicated. Again, although Rojek does engage to some degree with the history of millenaristic movements, he does not have much time for the dominant connotation of the term, which, as is the case for Messianism, might be said to reflect more the spectacular but accidental than the essential. For Rojek, millenarism has little to do with a literal interpretation of this or that isolated fragment of the Book of Revelation and is not primarily associated with niche fundamentalist religious sects (even if many of Rojek's romantic protagonists were, at least temporarily, part of something very much like a niche sect). What millenarism is really about according to Rojek are questions at once much more basic and arguably more important. Does human effort, and the "secular" progress brought about by such effort, have their place in the Christian story? Is the Kingdom of God that we simultaneously already proclaim and still await exclusively God's doing, or are we also allowed to say that it is, at some level, human doing or even human making? Perhaps human effort - technology,

5 P. Rojek, Liturgia dziejów, op. cit., p. 44. 
science, various political, societal, and economic improvements, but first and foremost this mundane, quotidian thing called "work" - can even be said to be necessary (albeit never sufficient) to achieve the state known as the Kingdom of God?

For Rojek, whenever the answers to these questions are in the affirmative (yes, the Kingdom of God is in some sense made closer by all human effort to "make the world a truly better place"), we can speak of millenarism, and it was precisely this kind of millenarism that the Polish romantics were articulating. By making place for human effort in the Christian narrative of the coming of the Kingdom of God, Rojek says, the Polish romantics - arguably the first mature, modern millenarists - were forerunners of a truly Christian modernity: a fusion of what is noblest in the modern projects, that is to say an effort to humanise the world, with what has always been central to Christianity, the primacy of God - His law, mercy, and grace. This fusion is understood to be bidirectional: just as the secular progress is incorporated into the Christian story, so also Christian religion permeates all "secular", public domains of life - to animate, guide, and elevate them from within. After all, the true human nature has been revealed in Christ - and so also a truly human world must be realised through Christian means and ultimately have a Christian form. Here, Rojek as much describes the ideas of romantics or Wojtyła as he proclaims his own, deeply influenced not only by Messianism but also, as I have already mentioned above, by the thinkers of the Russian spiritual renaissance, especially Solovyov, and by (post)modern theologies including Radical Orthodoxy. Rojek often repeats his Solovyovian dictum: "religion is either everything, or it is nothing." Of note, while Solovyov and other Russian thinkers might have been chronologically prior - and perhaps remain stronger - influences on Rojek, one of the claims of his book is that it is the Polish romantics that were first in the modern era to call for a religious re-integration in a manner that later became characteristic

6 P. Rojek, Liturgia dziejów, op. cit., p. 93, 294; cf. V. Solovyov, Lectures on Divine Humanity, transl. by B. Jakim, Hudson I995, p. r: "Religion must determine all the interest and the whole content of human life and consciousness [...]. All that is essential in what we do, what we know, and what we create, must be determined by and referred to such [religious] principle [...]. If the religious principle is admitted at all, it must certainly possess such all-embracing, central significance." 
of Russian thinkers.7 So, in some sense, Rojek is now going back to the cradle of his own theological sensitivity.

On this note, a justified question - but one to which Rojek's book does not provide a satisfactory answer - would be what were, in turn, the sources of Messianism itself. Of note, for Rojek, the Polish romantics not only endorsed many elements of modernity in their works, but also actually led quite modern lives. As he wrote, "Hoene-Wroński used in his philosophical works the most sophisticated recent methodology, Mickiewicz taught at a prestigious Western university [at Collège de France], Słowacki was making complicated financial transactions, and Cieszkowski implemented innovative modernising policies." One could also add that, perhaps most importantly, having emigrated from their homeland in the wake of a failed uprising, some of them lived in what was in some sense a great laboratory of modernity in nineteenth-century Paris. But at the same time, as is perhaps fitting for modern thinkers trained in secular sciences, the Polish romantics were not very familiar with the Catechism, let alone with the Councils, Fathers or Doctors of the Church. This was pointed out by their friend and critic, archbishop and saint Zygmunt Szczęsny Feliński, a character very much missing from Rojek's book. ${ }^{9}$

Therefore, although Rojek claims, somewhat convincingly, that Messianism restores original intuitions that were taken for granted in premodern Christianity, it is unclear how Mickiewicz or Słowacki would gain privileged access to these intuitions. One possible source was the Bible itself (Rojek claims Messianism to be a doctrine of an ultimately Biblical provenance, as suggested by the etymology of its name). If they read their Scriptures (did they?), their theological naivety might have actually helped to look at them afresh and recover some forgotten meanings. Still, one also expects that more contemporary influences played a role. Western romantic authors, for example, are bound to have been an inspiration; similarly, in the case of Parisian émigrés, quasi-religious utopian political movements such as Saint-Simonianism or Fourierism.

7 For relation between Polish Messianism and Russian religious philosophy see P. Rojek, The Trinity in History and Society. The Russian Idea, Polish Messianism, and the Post-Secular Reason, in: Apology of Culture. Religion and Culture in Russian Thought, eds. A. Mrówczyński-Van Allen, T. Obolevitch, P. Rojek, Eugene 2015, p. 24-42.

8 P. Rojek, Liturgia dziejów, op. cit., p. 94.

9 Z. S. Feliński, Trzej wieszczowie nasi wobec Kościota, Kraków Igı6. 
Mickewicz, for example, is known to have been introduced to the French utopian socialist movements by his translator, Bogdan Jański (interestingly, later one of the founders of the Catholic order of the Resurrectionists, whose history is intertwined with that of messianists; Rojek mentions this order, but, I think, not often enough). True, all these connections have in part already been described in the vast literature on Polish Romanticism. What Rojek could offer, however, is how Polish romantics managed to merge such influences with what seems, at least by his account, a more orthodox Christianity. Popular Polish religiosity might have been here at play, but if that were so, it would be interesting to see to what extent the romantics had, in their homeland and later in diaspora, contact with Catholic devotional practices and institutions, and what kind of teaching was on offer in the parishes of Vilnius and Paris at that time. Also, however much one might want to disconnect Messianism from Towiański, his influence - and the further influences that are mediated through him - should come under closer scrutiny. In the case of Cieszkowski, whose Ojcze nasz [Our Father] is arguably the most complete manifesto of romantic millenarism, one known influence is Hegel. Indeed, it is hard to miss the analogy between Messianism and Hegelianism with respect to, at least, the general tendency to immanentise and to dialectically reconcile apparent opposites. The Hegelian connection, however, remains unexplored by Rojek. It seems fitting to ask how much there really is of Hegel in Cieszkowski's works - and also those by the other romantics and their successors, all the way to Wojtyła's friend, the priest-philosopher Józef Tischner, a keen reader of The Phenomenology of Spirit. ${ }^{\text {o }}$

\section{Messianic Millenarism}

Perhaps most importantly, by focusing on millenarism, Liturgia dziejow enters the contemporary conversation about modernity and the possibility of reconciling it with religion. Rojek's take on this question is optimistic. True to Solovyov's appeal to make space within religion for "any living force in humanity or in its world" II (as well as an ear-

Io J. Tischner, Spowiedź rewolucjonisty. Czytając „Fenomenologię ducha” Hegla, Kraków I993.

II V. Solovyov, Lectures on Divine Humanity, op. cit., p. Io. 
lier messianic, and a later Wojtylan, appeal to the same effect), Rojek eschews a wholesale critique of modernity. We know from his other texts that he does, on the whole, subscribe to Henri de Lubac's thesis that modern secularisation started when theologians started speaking of two distinct human ends, a natural and a supernatural. ${ }^{\text {r2 }}$ But, Rojek's historical analyses, unlike those by some contemporary critics of modernity, are not aimed at uncovering foundational errors that would have made the whole modern legacy incurably flawed. For Rojek, despite the regrettable secularism that has been its part and parcel, many, perhaps most elements of modernity are valuable and hold great promise; indeed, they might even have a place in the Kingdom of God itself. Rather than a critique, Rojek seems to suggest, we need an integral narrative that would put these elements into their rightful place alongside more traditional ones, and above all - reconcile them with Christianity. Messianism, in its millenarist aspect, seems to provide such a narrative - and that's part of its lustre. Rojek shows that by taking inspiration from the messianists, Wojtyła was able to combine God-centred religious perspective with modern anthropocentrism - first in his poems, and later in homilies and pastoral letters. In his The David's Psalter (The Slavic Book), for example, Wojtyła calls for connecting the "Gothic" vertical love of God with the "Renaissance" horizontal love of the neighbour. ${ }^{13}$ As an archbishop, he tried to reconcile God and modern industrialism by supporting the creation of a parish church in the Krakow communist worker district of Nowa Huta. ${ }^{\text {I4 }}$

Here, missionism is also interesting. While some thinkers contrast premodern religious thinking, where identity was defined in terms of religions, with modern secular ideologies, where religion is replaced with a nation state, Rojek - following the romantics and Wojtyła is again more conciliatory. For them, the modern emphasis on nations might be reconcilable with religion if nations are not treated as an end in themselves but as having "missions" to fulfil in the process of building the Kingdom of God. Importantly, however, Rojek shows that, especially in the mature form of Messianism developed by Wojtyła, nations are not treated as ontologically independent substances that exist over and above their members. Rather, it is individual human persons

\footnotetext{
I2 See P. Rojek, The Trinity in History and Society, op. cit., p. 36.

I3 P. Rojek, Liturgia dziejów, op. cit., p. 150-I51.

I4 P. Rojek, Liturgia dziejórw, op. cit., p. I56-I57.
} 
that are called, qua members of their nations, to take responsibility for human history in a manner that is conditioned by their particular national characteristics and circumstances in which these nations find themselves. Wojtyła's missionism seems therefore more personalist, and thus more in line with current sociological tendencies, then essentialist theology of the nation of the Polish theologian Czesław Bartnik.

It must be stressed that Rojek, at least in this book, does not really go much into specific policies. He leaves it open, as it were, which elements of modernity - which economic or political doctrines, for example - can be reconciled with Christianity and which cannot. This openness seems to be deliberate. Those familiar with his work, especially with his previous book Konserwatyzm awangardowy [Avant-garde Conservatism], know that his is an eclectic strategy that, rather than aiming at a complete system, is satisfied with numerous individual interventions. ${ }^{15}$ These interventions can be theological or philosophical in nature, but also artistic; indeed, although not an artist himself, Rojek is keenly interested in the contemporary art scene. Liturgia dziejów should be seen as one particular intervention - an attempt to provide a meta-theory to the effect that religion and modernity can be reunited. It strikes me as not meant to be all-encompassing, although it does provide something like an overall framework which can now be filled with more specific, individual theoretical and practical interventions (not necessarily of Rojek's authorship, for he believes also in the division of labour). Of note, Rojek attributed a similar, "postmodern" strategy to John Paul II. ${ }^{16}$

Theologically, millenarism as described in Liturgia dziejów actually turns out to be the opposite of the apocalyptic thinking with which it is often associated and has more to do with the famous exegetical problem of the delayed Parousia ("Why isn't the end of the world happening yet?”). Here, Rojek's preferred metaphor - one used by romantics and further developed by Tischner and by Wojtyła - is a Eucharistic or liturgical one. (Indeed, that is where the enigmatic title of Rojek's book, Liturgia dziejów, comes from). Just like in the sacrament of the Eucharist "fruit of the earth and work of human hands"

I5 P. Rojek, Awangardowy konserwatyzm. Idea polska w póżnej nowoczesności, Kraków 2016.

I6 P. Rojek, Pokolenie kaptanów, proroków i królów? Mesjańska antropologia Jana Pawta II, "Pressje" 24 (20II), p. 29-30. 
must first be generated and offered by us to be subsequently completed and transformed by God, so also, within history, human work provides a raw material for further completion and transformation that God alone can bring about. One could add that, additionally, God is already present in some sense in all human work as the First Cause of all movement and the giver of grace. The Eucharistic metaphor expresses a sense of continuity or complementarity between human effort and God's supernatural action, one that is lacking in apocalyptic thinking, whereby the fruits of human creativity and labour are ultimately destroyed and replaced - rather than set straight and completed.

I found a surprising resonance between messianic ideas endorsed by Rojek and those of the English New Testament scholar and former Anglican Bishop of Durham, Nicholas Thomas Wright, especially as expressed in his lengthy The Resurrection of the Son of God ${ }^{17}$ and the popular Surprised by Hope. ${ }^{{ }^{8}}$ Rojek might find helpful for his argument Wright's interpretation of the Biblical representation of the second coming of Christ. Wright reminds us that one of the meanings of the Greek parousia is a meeting between the inhabitants of a city with a visiting ruler outside the city gates that is followed by the inhabitants escorting their ruler into the city itself, much like a family coming to an airport to welcome, and then bring home, their relative. Interpreted like this, second coming is not about humanity being snatched from the world they inhabit into a different reality - as fundamentalist apocalyptic rapture theologies would have it - but rather a welcoming of the Messiah into this reality so that He can judge, correct, and complete it. Wright might also help ground what Rojek calls millenarism in the Biblical tradition.

Distinguishing millenarism from apocalyptic thinking is of more than historical interest. By doing so, Rojek is able to identify the small but vibrant intellectual circle around the contemporary Polish Christian cultural journal "44 / Czterdzieści i Cztery” [44 / Forty and Four] - which brands itself as "messianistic" - as apocalyptic (at least as far as Rafal Tichy's manifestos are concerned) and thus at odds with the essence of real historical Messianism. ${ }^{19}$ The most recent is-

I7 N. T. Wright, The Resurrection of the Son of God, Minneapolis 2003.

I8 N. T. Wright, Surprised by Hope: Rethinking Heaven, the Resurrection, and the Mission of the Church, New York 2008.

I9 P. Rojek, Liturgia dziejów, op. cit., p. 286-294. 
sue of "44 / Czterdzieści i Cztery", which calls for "Divine anarchy" and "antipolitical Christianity," seems to confirm Rojek's diagnosis, for apocalyptic thinking will tend to shed responsibility for politically transforming the world. ${ }^{20}$ By the way, Rojek performs a similar analysis of Jarosław Marek Rymkiewicz, a contemporary Polish poet often referred to as representing Messianism. For all his interest in Mickiewicz, Rymkiewicz turns out to share with the romantics only their passionism, which sadly is not enough to be a real messianist, millenarism being its essential element.

For Rojek, the awareness of the incompleteness of human effort alone - and thus the necessity of an eschatological completion by God beyond history - is all that is required to make millenarism consistent with orthodox Christian, and specifically Catholic, doctrine. Rojek is well-aware of the teaching of the Catechism of the Catholic Church, which says in paragraph 676 that any attempt "to realize within history that messianic hope which can only be realized beyond history through the eschatological judgment" should be seen as "the Antichrist's deception." ${ }^{2 \mathrm{I}}$ In the same paragraph, "millenarism" is mentioned by name as a milder or "modified," and yet equally condemnable, form of this "deception." But what the Church really rejects in this and related statements, says Rojek, is the belief in human effort being sufficient to realise the Kingdom of God. ${ }^{22}$ For Rojek, real, orthodox, or "integral" millenarism - such as that of the romantics, Wojtyła, and Rojek himself - emphatically avoids this error by stressing the need for God's action. At the same time for Rojek this orthodox millenarism finally does justice to the doctrine that is also very present in the Catechism and especially in the teaching of the Second Vatican Council: that everything - all domains of reality, whether earthly or heavenly, temporal or eternal - must be subjected to Christ. It is precisely on this point that Messianism and the Council agree, allowing Wojtyła to stay true to his intuitions from student days while at the same time proclaiming the message of an official Church council as a pope.

While Rojek's defence of messianic millenarism against the argument from paragraph 676 does seem convincing, what might be seen as more problematic is that, at times, Rojek comes close to saying that

20 R. Tichy, Boska anarchia, "44 / Czterdzieści i Cztery” Io (2018), p. 4-57.

2I Catechism of the Catholic Church. Second Edition, Vatican City 2000, no. 676.

22 P. Rojek, Liturgia dziejów, op. cit., p. 63-65. 
human effort is necessary for the coming of the Kingdom of God. Isn't this in contradiction with another paragraph of the Catechism, 673, where it is stated that "This eschatological coming could be accomplished at any moment, even if both it and the final trial that will precede it are "delayed"? ${ }^{23}$ The language in this paragraph is that of optionality, of God's choice that has not been required or necessary. Why not rest with that language? Alternatively, although I'm not sure if it would be fully consistent with paragraph 673 and the teaching it articulates, we might say that while God could have realised various redemptive scenarios (which makes none of them really "necessary"), He has chosen to realise a specific one that involves the Incarnation of the Word of God; and perhaps in this particular scenario (but not absolutely), the "incarnational" unfolding of the Kingdom of God through human effort and suffering might be seen as necessary. Just like, although Christ's sacrifice is sufficient for redemption, we are still called to "fill up what is lacking in Christ's afflictions"(Colossians I:24), namely the particular living out of those afflictions in our own flesh, so also, although God's action is sufficient for bringing about the Kingdom of God, we might be called to be channels through which God can bring His transformative power to all particular moments and places of our created reality through its historical unfolding.

One possible problem with Rojek's messianistic millenarism is that it thinks the relationship between the human effort and God's transforming, "eschatological" action in horizontal terms: God comes after history. While this is in part justified by the linear Christian vision of created time, the Catechism uses the world beyond, which can also be interpreted vertically: God is not only our future, but also, as it were, gives a metaphysical "depth" or "height" to every individual moment of time. And His Kingdom, similarly, is not only in the future, but also somewhere "above" the history. I think that supplementing horizontal imagery with vertical one is important, as otherwise only the final state of the world really matters, while the rest of history does so only where there is a causal chain linking a given event with the final state. And what about failures and events without a lasting outcome? The logic of Resurrection, I think, demands that all such events can also have a place in the Kingdom of God. Good deeds do unfold their potential in time, giving rise to further good deeds. Real technological progress, 
for example, one that allows human beings to live more Godly lives, should, and I think does, lead to good and sainthood being more abundant (too bad, though, that, as Jacques Maritain and René Girard saw, not only good, but also evil increases in history). But even if some good deeds remain fruitless until the end of time, they are not forgotten; they wait like seeds in soil, to be completed beyond history.

\section{BibLIOGRAPHY}

Catechism of the Catholic Church. Second Edition, Vatican City 2000.

Feliński Z. S., Trzej wieszczowie nasi wobec Kościota, Kraków I9I6.

Froude J. A., Short Studies on Great Subjects, London 1907.

Rojek P., Awangardowy konserwatyzm. Idea polska w późnej nowoczesności, Kraków 2016.

Rojek P., John Paul II and the Polish Messianism. Introduction to the Liturgy of History, transl. by K. Popowicz, "Theological Research" 7 (2019), p. 9-27.

Rojek P., Liturgia dziejów. Jan Pawet II i polski mesjanizm, Kraków 2016.

Rojek P., Pokolenie kaptanów, proroków i królów? Mesjańska antropologia Jana Pawta II, "Pressje" 24 (20II), p. 28-38.

Rojek P., The Trinity in History and Society. The Russian Idea, Polish Messianism, and the Post-Secular Reason, in: Apology of Culture. Religion and Culture in Russian Thought, eds. A. Mrówczyński-Van Allen, T. Obolevitch, P. Rojek, Eugene 2015, p. 24-42.

Solovyov V., Lectures on Divine Humanity, Hudson 1995.

Suskiewicz M., Inna nowoczesność jest możliwa, "Suma" 6 (2017-2018), http:// pismosuma.pl/inna-nowoczesnose/ (22.04.202I).

Tichy R., Boska anarchia, "44 / Czterdzieści i Cztery" ro (2018), p. 4-57.

Tischner J., Spowiedź rewolucjonisty. Czytajac "Fenomenologie ducha” Hegla, Kraków 1993.

Wright N. T., The Resurrection of the Son of God, Minneapolis 2003.

Wright N. T., Surprised by Hope: Rethinking Heaven, the Resurrection, and the Mission of the Church, New York 2008. 